\title{
Maize cropping (Zea mays L.) assessment by simple performance-based index
}

\author{
Srđan Šeremešić $\cdot$ Ivica Đalović $\cdot$ Dragiša Milošev $\cdot$ \\ Aleksandra Nastasić · Borivoj Pejić · Marjana Vasiljević
}

\begin{abstract}
Summary: A simple performance-based index was used to test performance among maize cropping systems referring to the food and raw material production, nutrient cycling and greenhouse gases regulation. Those indices are tools for aggregating and simplifying agroecosystem impact on the environment. The data were acquired from a long-term experiment at the Rimski Sančevi experimental station of the Institute of Field and Vegetable Crops, Novi Sad, Serbia. Observed indicators were compared by using datasets from 2001 to 2010, across five maize cropping systems. Maize continuous cropping resulted with decrease in the utilization of the agroecological potential compared with the fertilized crop rotation. Long term maize-based cropping resulted with differences in soil organic carbon content, soil $\mathrm{pH}$ and temporal soil $\mathrm{NO}_{3}$. However, recommended fertilizers application and crop rotation contributed to the overall agroecosystems ability to decrease the anthropogenic pressure. Accordingly, it was found that yield decrease resulted mostly from inability of the cropping systems to utilize agricultural management (tillage, fertilization, etc.) in variable environmental conditions. For the investigated trial the performance based index showed that a 2-year maize cropping had the highest capacity for sustainable maize growing.
\end{abstract}

Keywords: agroecosystems, cropping systems, grain yield, maize, performances

\section{Introduction}

Maize is a cereal crop that is grown widely throughout the world in a wide range of agroecological conditions. In Serbia, maize is the largest crop, in both growth area and total productivity. Most of maize production in Serbia is rainfed with irregular rainfall and drought often reduces yield, particularly in the critical phases of maize development (Pejić et al. 2010). Lack of precipitation and lower soil fertility (mainly deficiency of nitrogen and phosphorus) can significantly reduce the production potential of the crop. Therefore, maize breeding and seed production have intensively been developing for the last 100 years and has been focused on hybrids with the enhanced potential for resource utilization (Jocković et al. 2010).

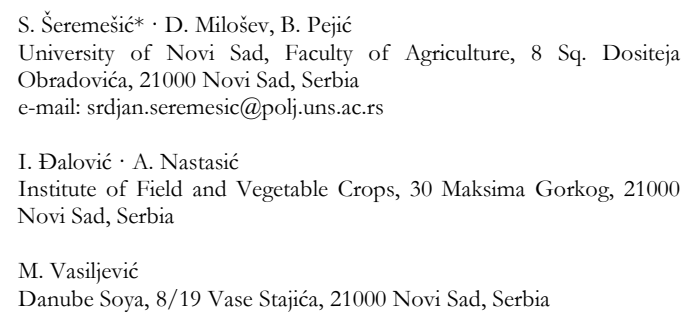

Development and intensification of the agricultural production is necessary because of the food demand of the world's growing population, although the economic problems can impede projected growth. At the same time, there is a raising awareness of the negative consequences associated with the agricultural production. Of all human activities, agriculture alters the global environment to the greatest extent (CAST, 1994), because it involves utilization of the different natural resources and a different processing technology. According to Bellarby et al. (2008) agriculture, forestry and other land use is estimated to be responsible for around 17 $-31 \%$ of anthropogenic greenhouse gases (GHG) emissions, and there is a significant potential for reducing those emissions, largely through improved agricultural management. Hence, overall tendency is that agricultural GHG will continue to rise for the foreseeable future as agricultural production expands to provide food, feed, fibre and bioenergy. Diversification of agricultural landscapes and cropping systems offers one of the best and most accessible strategies for resolving the seemingly intractable tension between agricultural production and environmental quality (Liebman et al. 2013).

Acknowledgements: This study is part of the TR 031073 project financially supported by the Ministry of Education, Science and Technological Development of the Republic of Serbia. 
A wider understanding of the agricultural context requires the study between agriculture, the global environment and social systems given that agricultural development results from the complex interaction of a multitude of factors (Altieri 2005). Sustainability for agriculture implies food and fibre production with a mission: production which guarantees ecological stability, economic viability and socio-cultural permanence (Lal 1991). It is almost impossible to measure sustainability directly and it is too difficult to define a concept and it operates over too long a time scale. What we can do is to identify measurable occurrence that, when put together, suggest how sustainable our cropping system might be with appropriate tools called indicators. Assessing the environmental sustainability of agricultural systems in a quantitative manner requires the identification and integration of diverse phenomena of "indicators" of environmental effects, in a framework consistent with the evolving concept of sustainability (Sands \& Podmore 2000). Agro-environmental indicators are main tools for evaluating the impact of agriculture to environment (Girardin et al. 1999). A simple performance-based index was developed to determine the relative sustainability of agricultural management system within the context of multiple agroecosystem functions and to give users a simple measure to assess sustainability of agricultural practices (Liebig et al. 2001). This index provides a measure of the performance of an agricultural system over time, in contrast to representation of its state or condition at any one particular time.

The aim of this study was to evaluate the maize cropping with performance based index using data set from a long-term experiment.

\section{Material and Methods}

For this study data were taken from different cropping systems of a long-term experiment "Plodoredi". This long-term experiment (LTE) has been carried out at the Rimski Sančevi Experimental Field of the Institute of Field and Vegetable Crops in Novi Sad, Serbia $\left(45^{\circ} 19^{\prime} \mathrm{N}, 19^{\circ} 50^{\prime} \mathrm{E}, 84 \mathrm{~m}\right)$. The trial was established in 1946/47 in order to improve production and conservation properties of chernozem soil. In 1970 new crop rotation systems were introduced in order to examine their effect on the yield of most important crops in Vojvodina Province (Šeremešić 2005). Attributes of the crop management are predefined, such as management practices and the geo-physical characteristics of the experiment and considered homogenous for study period, limited vertically by crop and the soil profile as defined by input data (Sands \& Podmore 2000).

For calculating the performance based index we used dataset from 2001 to 2010 year from the long- term experiment "Plodoredi". Regarding the year of the trial establishment, selected period in our study could encompass the cumulative effects of treatments on the performance based index. The study treatments were as follows:

1. 3-year crop rotation (maize-soybean-winter wheat), mineral fertilizer $120 \mathrm{~kg} \mathrm{~N} / \mathrm{ha}+$ crop residues (D3);

2. 2-year crop rotation (maize-winter wheat), mineral fertilizer $120 \mathrm{~kg} \mathrm{~N} / \mathrm{ha}+$ crop residues (D2);

3. maize continuous cropping, mineral fertilizer $120 \mathrm{~kg} \mathrm{~N} / \mathrm{ha}+$ crop residues (MO);

4. 2-year rotation (maize-winter wheat), without fertilizers + crop residues $(\mathrm{N} 2)$;

5. 3-year rotation (maize- soybean-winter wheat), without fertilizers + crop residues $(\mathrm{N} 3)$.

The calculation of performance-based index is led by four basic steps: data grouping, calculation of averages, ranking and scoring treatments, and summing of scores within and across agroecosystem functions. First step contains group data within agroecosystem functions. The procedure is initiated by surveying the dataset for indicators that could be grouped within agroecosystem functions (Liebig et al. 2001). Ecosystems services are benefits that people and other organisms obtain from ecosystems such as pollination, clean water and air, nutrient cycling scenic landscapes, wildlife habitat, biodiversity, etc. (De Groot et al. 2002). For the purpose of this analysis, ecosystem services were grouped into 17 major categories. Indicators included in the procedure were categorized into four agroecosystem functions following general guidelines presented by Javazadeh et al. (2014). The analysis considered the entire system, but we used the most relevant ones for our study: food production, raw material production, nutrient cycling, and greenhouse gas regulation. Within each agroecosystem, indicators were selected to characterize the performance of specific function (Liebig et al. 2001). The next step was calculation of treatments averages for each indicator. It is important to make a difference between indicators, because some of them are best evaluated over time, whereas the others are cumulative in their influence on agroecosystem functions, increasing or decreasing over time (Table 1).

After calculation of averages for each indicator, it is necessary to rank and score treatments. According to Liebig (2001), treatment values are ranked for each indicator in ascending or descending order, depending on whether a higher value for the indicators are good or bad. After the treatment values are ranked, they are scored based on their relative differences from the optimal value (Table 2). 
Table 1. Different cropping systems averages for indicators used to represent agroecosystem functions

\begin{tabular}{|c|c|c|c|c|c|}
\hline \multirow{2}{*}{$\begin{array}{l}\text { Agroecosystem indicators } \\
\text { (average for 2001-2010) }\end{array}$} & \multicolumn{5}{|c|}{ Cropping systems } \\
\hline & D2 & D3 & $\mathrm{MO}$ & N2 & N3 \\
\hline \multicolumn{6}{|l|}{ Food production } \\
\hline Grain yield, $\mathrm{kg} / \mathrm{ha}$ & 6230.50 & 6552.43 & 3926.10 & 2009.80 & 2862.00 \\
\hline Grain $\mathrm{N}$ content, $\mathrm{g} / \mathrm{kg}$ & 98.32 & 103.14 & 64.78 & 22.63 & 71.27 \\
\hline \multicolumn{6}{|l|}{ Raw materials production } \\
\hline Stover yield, $\mathrm{kg} / \mathrm{ha}$ & 7929.20 & 8339.05 & 4798.00 & 2177.00 & 3100.50 \\
\hline Stover $\mathrm{N}$ content, $\mathrm{g} / \mathrm{kg}$ & 42.48 & 46.88 & 29.48 & 11.725 & 21.46 \\
\hline \multicolumn{6}{|l|}{ Nutrient cycling* } \\
\hline Residual soil $\mathrm{NO}_{3}-\mathrm{N}, 0-90 \mathrm{~kg} / \mathrm{ha}$ & 47.18 & 78.00 & 40.00 & 28.25 & 38.00 \\
\hline Soil $\mathrm{pH}$ & 7.29 & 7.59 & 7.56 & 7.62 & 7.60 \\
\hline \multicolumn{6}{|l|}{ Greenhouse gas regulation } \\
\hline Soil organic $\mathrm{C}, \mathrm{kg} / \mathrm{ha}$ & 40.56 & 40.16 & 39.24 & 20.9 & 35.24 \\
\hline Early spring soil $\mathrm{NO}_{3}-\mathrm{N}, \mathrm{kg} / \mathrm{ha}^{*}$ & 22.99 & 38.00 & 25.00 & 15.25 & 20.00 \\
\hline
\end{tabular}

*Adapted from Šeremešić et al. (2009) and Bogdanović et al. (2010)

Table 2. Rank and score treatments for indicators within agro-ecosystem functions (rank 1 indicate higher score, rank 5 indicate lowest score)

\begin{tabular}{|c|c|c|c|c|c|}
\hline Rank & Treatments & Score & Rank & Treatments & Score \\
\hline \multicolumn{6}{|c|}{ Food production } \\
\hline & Grain yield* & & & Grain $\mathrm{N}$ & \\
\hline 1 & D3 & 1.00 & 1 & D3 & 1.00 \\
\hline 2 & D2 & 0.95 & 2 & D2 & 0.95 \\
\hline 3 & $\mathrm{MO}$ & 0.59 & 3 & N3 & 0.69 \\
\hline 4 & N3 & 0.43 & 4 & $\mathrm{MO}$ & 0.62 \\
\hline 5 & $\mathrm{~N} 2$ & 0.30 & 5 & N2 & 0.21 \\
\hline \multicolumn{6}{|c|}{ Raw materials production } \\
\hline & Stover yield* & & & Stover 1 & \\
\hline 1 & D3 & 1.00 & 1 & D3 & 1.00 \\
\hline 2 & D2 & 0.95 & 2 & D2 & 0.90 \\
\hline 3 & $\mathrm{MO}$ & 0.57 & 3 & $\mathrm{MO}$ & 0.62 \\
\hline 4 & N3 & 0.37 & 4 & N3 & 0.46 \\
\hline 5 & $\mathrm{~N} 2$ & 0.26 & 5 & N2 & 0.25 \\
\hline \multicolumn{6}{|c|}{ Nutrient cycling } \\
\hline & Residual $\mathrm{NO}_{3}-\mathrm{N}^{*}$ & & & & \\
\hline 1 & N2 & 1.00 & 1 & N2 & 1.00 \\
\hline 2 & N3 & 0.74 & 2 & N3 & 0.99 \\
\hline 3 & MO & 0.71 & 3 & D3 & 0.99 \\
\hline 4 & D2 & 0.60 & 4 & MO & 0.99 \\
\hline 5 & D3 & 0.36 & 5 & D2 & 0.96 \\
\hline \multicolumn{6}{|c|}{ Green house regulation } \\
\hline & Soil organic $C^{*}$ & & & Early sprit & \\
\hline 1 & D2 & 1.00 & 1 & N2 & 1.00 \\
\hline 2 & D3 & 0.99 & 2 & N3 & 0.76 \\
\hline 3 & $\mathrm{MO}$ & 0.97 & 3 & D2 & 0.66 \\
\hline 4 & N3 & 0.86 & 4 & $\mathrm{MO}$ & 0.61 \\
\hline 5 & N2 & 0.52 & 5 & D3 & 0.40 \\
\hline
\end{tabular}

*Data for food production, stover yield and $\mathrm{N}$ content, and soil organic $\mathrm{C}$ ranked in descending order with the highest value given a score of 1.0. Lower values were scored by division with the highest value.

fData for soil $\mathrm{NO}_{3}$ ranked in ascending order with the lowest value given a score of 1.0. Higher values were scored by dividing the lowest value by each higher value $\$$ Soil $\mathrm{pH}$ scored using a threshold value of 7.0 , dividing each lower value by the threshold, and dividing the threshold by each higher value. 
Upon summing scores within agroecosystem functions, the remaining step was to sum scores across functions to get total score. Finally, obtained total score was divided with maximum score (8) to rank individual cropping system. According to Liebig and Varvel (2003), the final score reflected a relative ranking of overall agroecosystem performance among treatments for functions included in procedure, scores were scaled to 100 to express them in simple context (Table 3). The regression analysis was conducted to detect the effect of indices on agroecosystem performance scores by using the program Statistica 12.6.

\section{Results and Discussion}

Comparison of individual treatments showed that the long term maize cropping resulted in differences in the agroecosystem performance. According to Liebig \& Varvel (2003), quantifying the effects of management practices on agroecosystem functions is necessary to evaluate the sustainability of cropping systems. Therefore, attained yield in the long-term trials could be a basis for calculating the adaptability of the particular cropping systems to the environmental conditions (Zorić et al. 2014). For the fertilized treatments the overall agroecosystem performance score for fertilized maize 2-year rotation was 87.12, for fertilized 3-year rotation 84.37, and 71.00 for maize monocropping (Table 3). The maize monocropping which resulted in higher sustainability compared with N2, N3, suggested that, in the period of 10 years, fertilization could be more important than crop rotation when overall maize performance is discussed. Higher score observed at the 2-year rotation can be explained with the frequency of maize in rotation as a crop that retrieves the higher crop biomass that is incorporated in the soil. In addition to that, it is commonly considered that winter wheat in a 2 -year rotation is a good preceding crop for maize.

In the earlier study inconsistent results were obtained. The simple regression analysis of the data set from the same experimental field indicated that 2-year and 3-year maize fertilized rotation was the most suitable for maize growing in our agroecological conditions. However, relative maize yield stability showed that the maize monocropping $(r=0.76)$ and a 2 -year rotation $(r=0.73)$ were the most dependent on availability of the environmental resources $(P<0.05)$ (Šeremešić et al. 2013). Similar results were presented by Pepó (2009), where the yield-increasing effect of maize rotation on yield was inversely proportional to the ratio of maize in the crop sequence. Smith at al. (2008) also reported that the legumes appeared to have strong effects on ecosystem functions that follow maize yield increase. Karlen et al. (1994) argued that cropping system diversification through the use of multispecies crop rotations can maintain soil fertility and productivity irrespective to fertilization. Therefore, it can be concluded that the rotation could exhibit positive effects on yield in a long term, whereas effects of the fertilization is ascribed to the synergistic interaction between nutrient and environment (Grover et al. 2009).

The unfertilized rotations were lower in the overall agroecosystem performance as a result of the small biomass production that in a long term is insufficient to compensate losses of soil organic matter and available nutrients (Šeremešić 2005). In addition to that, poor soil fertility of N2 and N3 cropping systems caused slower plant vegetative growth and intensive weed infestation. As a result of weed cover and slowdown of the vegetative growth, soil physical properties were changed, particularly soil water regime. Similar to our study, aridity index calculation for maize at the same location revealed higher correlation between the climatic conditions and maize yield (Pejić et al. 2011).

Based on the observed indices for all cropping systems, crop yield as well as raw material production has higher differences between minimum and maximum values, compared with the nutrient cycling and greenhouse gases regulation. According to Milošev et al. (2014), a 3-year rotation of winter wheat from the same long-term experiment had higher performancebased index compared with other winter wheat cropping systems. This is in disagreement with the calculated indices for maize cropping where 2-year maize rotation showed higher agroecosystem performance score. Increased productivity of 3-year winter wheat cropping compared with other winter wheat system could be based upon a multi-cropping that in the long-term increases yields. Conversely in our study performance based index of 3-year rotation was lower than 2-year fertilized maize rotation. Maize cultivation for the study period 2001-2010 demonstrated that high yield and yield stability were not mutually exclusive. However, these findings can be detected only in the continual long-term experiments. Therefore, results suggested that in our agroecological conditions 3-year crop rotation with the following arrangement of crops: maize-soybean-winter wheat could be more beneficial for winter wheat compared to maize growing. Similar result was presented in Berzsenzyi et al. (2000) for long-term experiment in Martonvásár where rotation effect on maize yield is attributed to $\mathrm{N}$ effects of preceding crop.

Raw material $(r=-0.92)$ and food production $(r=-0.05)$ showed negative correlation with the agroecosystem performance (Table 3 ). Higher biomass (vegetative growth) usually requires more resources (water, nutrients and gasses) and conversion (recycling) of those inputs is uncertain each year. On the contrary, greenhouse gas regulation has positive effects on agroecosystem performance. Higher values for soil organic carbon represented reduced loss to the atmosphere while lower levels of early spring soil $\mathrm{NO}_{2}$ represented decreased potential for $\mathrm{N}_{2} \mathrm{O}$ emissions from denitrification. 
Table 3. Agroecosystem performance (AESP) scores for different maize cropping systems

\begin{tabular}{lcccccc}
\hline \multirow{2}{*}{ Treatments } & \multicolumn{4}{c}{$\begin{array}{c}\text { Agroecosystem } \\
\text { Functions }\end{array}$} & \multicolumn{2}{c}{$\begin{array}{c}\text { Agroecosystem performance } \\
\text { scores }\end{array}$} \\
\cline { 2 - 7 } & $\begin{array}{c}\text { Food } \\
\text { production }\end{array}$ & $\begin{array}{c}\text { Raw materials } \\
\text { production }\end{array}$ & $\begin{array}{c}\text { Nutrient } \\
\text { cycling }\end{array}$ & $\begin{array}{c}\text { Greenhouse gas } \\
\text { regulation }\end{array}$ & $\begin{array}{c}\text { Total } \\
\text { score }\end{array}$ & Scaled to 100 \\
\hline D2 & 1.90 & 1.85 & 1.56 & 1.66 & 6.97 & 87.12 \\
D3 & 2.00 & 2.00 & 1.36 & 1.39 & 6.75 & 84.37 \\
MO & 1.21 & 1.19 & 1.70 & 1.58 & 5.68 & 71.00 \\
N3 & 1.12 & 0.83 & 1.74 & 1.62 & 5.31 & 66.37 \\
N2 & 0.51 & 0.51 & 2.00 & 1.52 & 4.54 & 56.75 \\
\hline Correlation to & -0.05 & -0.92 & 0.97 & 0.98 & - & - \\
AESP & & & &
\end{tabular}

In maize cropping, Liebig and Varvel (2003) found negative correlation between production and environmental protection related functions. Ma et al. (2012) study of maize production in the north-eastern China also concluded that soil organic carbon and total $\mathrm{N}$ declined from the initial level, and were key soil properties to improve maize yield and stability. In addition to that, it could be assumed that balanced cropping systems are those with the higher agroecosystems performance.

\section{Conclusions}

The agroecosystem performance index was a successful tool for comparison of the cropping systems. Long-term cropping has resulted with differences in soil organic carbon, soil $\mathrm{pH}$ and temporal soil $\mathrm{NO}_{3}$. However, appropriately managed agroecosystems were able to compensate the anthropogenic pressure and responded with resilience to the applied cropping technology over the years.

Accordingly, it was found that yield decline resulted mostly from poor adaptation to climate condition, and fertilization had the main effects on yield preservation. For the investigated period 2-year maize rotation was indicated as a cropping system with higher performance-based index.

\section{References}

Altieri, A. M. (2005). Agn-ecology: principles and strategies for designing sustainable farming systems. University of California, Berkeley.

Bellarby, J., Foereid, B., Hastings, A., \& Smith, P. (2008). Cool Farming: Climate Impacts of Agriculture and Mitigation Potential. Greenpeace International, Amsterdam, the Netherlands.

Berzsenzyi, Z., Győrffy, B., \& Lap, D. (2000). Effect of crop rotation and fertilization on maize and wheat yields and yield stability in long termexperiment. Eur J. Agron, 13, 225-244.

Bogdanović, D., Milošev, D., Šeremešić, S., Jug, I., \& Đalović, I. (2010). Mineral nitrogen dynamic in soil of different fertility as affected by agroeconomic practices. Contemp. Agri., 59(3-4), 278-287.

CAST - Council for Agricultural Science and Technology (1994). Pesticides in surface and ground water. Issue paper No. 2

De Groot, R. S., Wilson, M. A., \& Boumans, R. M. (2002). A typology for the classification, description and valuation of ecosystem functions, goods and services. Ecol. Econ. 41(3), 393-408.

Girardin, P., Bockstaller, C., \& Werf, H. V. D. (1999). Indicators: tools to evaluate the environmental impacts of farming systems. J. Sustain. Agrm, 13(4), 5-21.

Grover, K.K., Karsten, H.D., \& Roth, G.W. (2009). Com grain yields and yield stability in four long-term cropping systems. Agron. J., 101, 940-946.
Javazadeh, S.M., Mehraban, A., Ebrahami, A., \& Hmed, J. (2014). AgriEnvironmental: a review. Adv. Agric. Biol., 1, 93-104.

Jocković, Đ., Stojaković, M., Ivanović, M., Bekavac, G., Popov, R., \& Đalović, I. (2010). NS hibridi kukuruza - danas i sutra. Ratar. Porrt., 47(1), 325-333.

Karlen, D.L., Varvel, G.E, Bullock, D.G., \& Cruse, R.M. (1994). Crop rotations for the 21st century. Adv. Agron., 53, 1-45.

Lal, R. (1991). Soil structure and sustainability. J. Sustain. Agric. 1, 67-91.

Liebig, M., \& Varvel, G.E. (2003). Effects of Western Corn Belt Cropping Systems on Agro-ecosystem Functions. Agron. J., 95, 316 -322 .

Liebig, M.A., Varvel, G.E., \& Doran, J. (2001). A Simple PerformanceBased Index for Assessing Multiple Agro-ecosystem Functions. Agron. J., 93, 313-314.

Liebman, M.Z, Helmers, M.J, Schulte, L.A., \& Chase, CA. (2013). Using biodiversity to link agricultural productivity with environmental quality: results from three field experiments in Iowa. Ren. Agric. Food Sys., 28, 115-128.

Ma, Q., Yu, W.T., Jiang, C.M., Zhou, H., \& Xu, Y.G. (2012). The influences of mineral fertilization and crop sequence on sustainability of corn production in northeastern China. Agri, Ecos. Environ., 158, 110-117.

Milošev, D., Šeremešić, S., Đalović, I., \& Jaćimović, G. (2014). Assessing the agro-ecosystem performance in a long-term winter wheat cropping. Contemp. Agri. 63: 494-500.

Pejić, B., Jaćimović, G., Latković, D., Bošnjak, Đ., Marinković, B., \& Mačkić, K. (2011). Indeks aridnosti kao osnova analize uticaja režima padavina i temperature vazduha na prinos kukuruza u Vojvodini. Ratar. Povrt., 48(1), 195-202.

Pejić, B., Maksimović, L., Milić, S., Simić, D., \& Miletaški, B. (2010). Uticaj deficita lakopristupačne vode u zemljištu na prinos $i$ evapotranspiraciju kukuruza. Ratar. Povrt., 47(1), 115-121.

Pepó, P. (2009). Yield and lodging of maize (Zea mays L.) in a droughty and wet crop year on chernozem soil. Crop Production, 58, 53-66.

Sands, G.R., \& Podmore, T.H. (2000). A generalized environmental sustainability index for agriculture systems. Agric. Ecosyst. Environ., $79,29-41$.

Šeremešić, S. (2005). Effect of crop rotation and fertilization on the physical and chemical properties of chernozem (in Serbian). Master's thesis, University of Novi Sad, Faculty of Agriculture.

Šeremešić, S., Bogdanović, D., Milošev, D., Marinković, B., Latković, D., \& Jaćimović, G. (2009). Distribucija i dinamika $\mathrm{NO}_{3}-\mathrm{N}$ u sistemu ratarenja kukuruz-pšenica. Letopis naučnih radova, 33(1), 69-76.

Šeremešić, S., Đalović I., Milošev, D., Jocković, Đ., \& Pejić, B. (2013). Maize (Zea mays L.) yield stability dependence on crop rotation, fertilization and climatic condition in a long-term experiment on Haplic Chernozem. Zemdirbyste, 100(2), 137-142.

Smith, R.G., Gross, K.L., \& Robertson, G.P. (2008). Effects of crop diversity on agroecosystem function: crop yield response. Ecosystems, 11(3), 355-366.

Zorić, M., Mitrović, B., Stanisavljević, D., Ivanović, M., Bekavac, G., Živanov, D., \& Mirosavljević, M. (2014). Comparison of Biplot Analysis and Kang's YSi Statistic in Estimating Maize Hybrids Stability. Ratar: Povrt., 51(3), 154-160. 


\section{Procena indeksa efikasnosti sistema gajenja kukuruza (Zea mays L.) u višegodišnjem eksperimentu}

\section{Srđan Šeremešić · Ivica Đalović · Dragiša Milošev •} Aleksandra Nastasić · Borivoj Pejić · Marjana Vasiljević

Sažetak: U radu je prikazana analiza indeksa performansi agroekosistema koja može da posluži kao osnova za unapređenje gajenja kukuruza. Indeksi performansi sistema gajenja kukuruza su korišćeni u cilju razdvajanja njihove efikasnosti u ostvarivanju visine prinosa, količine biljnih ostataka, kruženja hraniva i regulaciji gasova staklene bašte. Korišćeni indikatori su indirektni pokazatelji koji služe za sumiranje i pojednostavljenje tumačenja kompleksnog uticaja agroekosistema na životnu sredinu. Za obračun su korišćeni podaci sa višegodišnjeg ogleda "Plodoredi" Instituta za ratarstvo i povrtarstvo iz Novog Sada, a praćeno je pet različitih sistema gajenja kukuruza. Istraživani sistemi ratarenja, posmatrano u dužem vremenskom periodu, značajno su uticali na svojstva zemljišta, što je dovelo do razlika u sadržaju organske materije, $\mathrm{pH}$ vrednosti i zemljišnog $\mathrm{NO}_{3}$. Međutim, pravilno postavljena tehnologija gajenja kod đubrenih polikultura kukuruza je uspešno kompenzovala antropogeni uticaj. U skladu sa tim, istraživanja su pokazala da opadanje prinosa dolazi kao rezultat smanjene efikasnosti pojedinih sistema gajenja kukuruza da iskoriste efekte primenjene agrotehnike (đubrenje, obradu) pri varijabilnim klimatskim uslovima. Utvrđeno je da dvopolje kukuruza ima najveći indeks efikasnosti i sposobnost da raspolaže resursima agroekosistema, dok neđubrene parcele dugoročno nemaju mogućnost očuvanja agroekosistema.

Ključne reči: agroekosistem, kukuruz, performanse, prinos zrna, sistem ratarenja 